\title{
Study of some engineering properties of dry chilli (Capsicum annuum L.) cultivars of India
}

G. Srinivas, P.S. Champawat, V.D. Mudgal, S.K. Jain and D. Sharma

Received : 10.06.2020; Revised : 04.08.2020; Accepted : 03.09.2020

See end of the Paper for authors' affiliation Correspondence to :

G. Srinivas

Department of Processing and Food Engineering, College of Technology and Engineering (MPUAT), Udaipur (Rajasthan) India Email: sgirjals@gmail.com
- ABSTRACT : This paper describes some of the engineering properties of six chilli (Capsicum annuum L.) cultivars, viz., Byadgi, Guntur sanam, Mathania, Kashmiri, Reshampatti and Teja which would aid in designing the equipment and apparatus for processing of dry chilli such as sorting, grading drying, destalking, size reduction and transportation. The significant difference was observed among the geometrical properties (length, width, and thickness), gravimetric properties (bulk and true density), optical (color scales $\mathrm{L}^{*}, \mathrm{a}^{*}, \mathrm{~b}^{*}$ ), aerodynamic (terminal velocity), mechanical (hardness) and frictional (co-efficient of friction). Among geometrical properties, the whole fruit lengths were ranged from 83.83 to $146.03 \mathrm{~mm}$, width 9.66 to $41.41 \mathrm{~mm}$ and thickness 3.86 to $11.11 \mathrm{~mm}$. The stalk length, width and crown height of the fruit ranged from 25.90 to $34.87,3.03$ to 5.64 and 4.11 to 8.43 , respectively, these values can be used to fabricate chilli destalking machine. The bulk and true density were observed from 100 to $130 \mathrm{~kg} / \mathrm{m}^{3}$ and 260 to $560 \mathrm{~kg} / \mathrm{m}^{3}$, respectively, these values can be used to design the hopper or in vacuum packing. Colour scales varied from 19.80 to 27.56 for $\mathrm{L}^{*}, 7.21$ to 23.15 for $\mathrm{a}^{*}$ and 8.53 to 17.61 for $\mathrm{b}^{*}$, these values may be used to colour graders for grading the chilli based on colour. The hardness of the fruit pod varied from 37 to $198.03 \mathrm{~N} / \mathrm{mm}^{2}$ and for stalk from 32.83 to $127.54 \mathrm{~N} / \mathrm{mm}^{2}$, these values may be used to design size reducing, seed extracting equipment. The terminal velocity (experimental and theoretical) values varied from 3.66 to $9.03 \mathrm{~m} / \mathrm{s}$ and 5.33 to $10.69 \mathrm{~m} / \mathrm{s}$, respectively, these values may be used to design dryers. Coefficient of friction values for MS, aluminum and for steel varied from 0.46 to $0.65,0.36$ to 0.55 and 0.34 to 0.48 , respectively, these values may be used in designing the hopper, conveyors and destalking machines.

- KEY WORDS : Chilli, Destalking, Mechanization, Destemming, Guntur sanam

-HOW TO CITE THIS PAPER : Srinivas, G., Champawat, P.S., Mudgal, V.D., Jain, S.K. and Sharma, D. (2020). Study of some engineering properties of dry chilli (Capsicum annuum L.) cultivars of India. Internat. J. Agric. Engg., 13(2) : 160-166, DOI: 10.15740/HAS/IJAE/13.2/160-166. Copyright@2020: Hind Agri-Horticultural Society. 